\title{
TRANSACTION COST ANALYSIS ON REVENUES AND PROFITS OF RED CHILI FARMING
}

\author{
Zumi Saidah")1, Harianto**), Sri Hartoyo ${ }^{* * *}$, and Ratna Winandi Asmarantaka*) \\ *) Faculty of Agriculture, Universitas Padjadjaran \\ Jl. Raya Bandung Sumedang KM 21, Jatinangor 45363 \\ **) Department of Agribusiness, Faculty of Economics and Management, IPB University \\ Jl. Agatis, Campus of IPB Darmaga Bogor 16680 \\ ${ }^{* * *}$ Department of Economics, Faculty of Economics and Management, IPB University \\ Jl. Agatis, Campus of IPB Darmaga Bogor 16680
}

\begin{abstract}
This research aimed to analyze the transaction cost structure and the effect of transaction costs on the revenue and profit of red chili farming. The analytical methods used were Transaction Cost Economic (TCE) analysis and multiple regression analysis. This research was conducted in Garut Regency, West Java, on 145 farm households. The research results showed that the highest percentage of transaction cost components was at implementation costs of 25.1 percent, followed by information search costs of 23.1 percent and negotiation costs of 22.3 percent. The number of transaction costs formed in red chili farming was IDR 3,990 727.74 per year. The ratio of transaction costs to total costs was 0.0285 . This indicated that farmers had to issue 2.85 percent of the total costs for transaction costs. In addition, the percentages of transaction costs for revenue and profit of red chili farming were 4.65 and 5.27 percent respectively. The results also showed that five variables had significant effects on the benefits of red chili farming. The five variables included the price of chilli seeds, manure, insecticides, labor wages, and transaction costs.
\end{abstract}

Keywords: transaction cost, production cost, red chili, profit, revenue

\begin{abstract}
Abstrak: Penelitian ini bertujuan menganalisis struktur biaya transaksi dan menganalisis pengaruh biaya transaksi terhadap penerimaan dan keuntungan usahatani cabai merah. Adapun metode analisis yang digunakan adalah analisis Transaction Cost Economic (TCE) dan analisis regresi berganda. Penelitian ini dilakukan di Kabupaten Garut Jawa Barat terhadap 145 rumahtangga petani. Hasil peneltian menunjukkan bahwa persentase komponen biaya transaksi tertinggi terdapat pada biaya pelaksanaan sebesar 25,1 persen yang diikuti oleh biaya pencarian informasi sebesar 23,1 persen dan biaya negosiasi sebesar 22,3 persen. Jumlah biaya transaksi yang terbentuk pada usahatani cabai merah yaitu sebesar Rp 3990727.74 per tahun. Rasio biaya transaksi terhadap total biaya sebesar 0.0285. Artinya petani harus mengeluarkan 2,85 persen dari total biaya untuk biaya transaksi. Selain itu, persentase biaya transaksi terhadap penerimaan dan keuntungan usahatani cabai merah sebesar 4.65 dan 5,27 persen. Hasil penelitian juga menunjukkan bahwa terdapat lima variabel yang berpengaruh nyata terhadap keuntungan usahatani cabai merah. Kelima variable tersebut meliputi harga benih cabai, harga pupuk kandang, harga obat hama, upah tenaga kerja, dan biaya transaksi.
\end{abstract}

Kata kunci: biaya transaksi, biaya produksi, cabai merah, keuntungan, penerimaan

\footnotetext{
${ }^{1}$ Corresponding author:

Email: zumi.saidah@unpad.ac.id
} 


\section{INTRODUCTION}

Horticulture is the second largest agricultural subsector after food crops with an estimated involvement of 9.3 million farmers, or around $23 \%$ of the total 41.5 million farmers in Indonesia. Based on the percentage of vegetable production in Indonesia, there are 5 (five) types of vegetable crops contributing the largest production to the total national vegetable production; i.e. cabbage (12.05\%), potatoes (11.31\%), shallots (10, $35 \%)$, large chili $(9.02 \%)$ and tomatoes $(7.69 \%)$, while 20 other types of vegetables have less than seven $\%$ of production (Director General of Horticulture 2015). One horticultural commodity that has high economic commodity value and a strategic role in the structure of the national economy is the commodity of red chili (Saptana et al. 2012).

Red chili (Capsicum anunum L) is the second largest type of horticulture plant cultivated by farm households after cayenne pepper. Demand for red chili tends to be constant, only at certain times the demand will increase by $10-20 \%$, while supply is seasonal (Yanuarti and Afsari, 2016). The price of red chili is very fluctuating reflected by the large numbers of supply and demand (Saptana, 2010). Commodity prices for red chilli and shallots tend to fluctuate and have a high margin level which results in inefficient established prices (Suwarsinah et al. 2018).

According to Nurhayanti (2017), the supply of red chili commodity is still largely dependent on the amount of chili produced, while the amount of chili production is largely determined by harvest areas and land productivity. This is in line with the findings of Pusdatin (2017) stating that chili production in Indonesia over the past five years (2012-2016) has a rising trend with a growth rate of $5.82 \%$ per year. The increase in the national chili production was influenced by an increase in harvested area which increased by $1.63 \%$ per year and productivity with a growth rate of $4.26 \%$ per year.

As we have seen, farmers are interested in planting red chili because of the high economic potential compared to other vegetable crops. The economic value of red chili commodity is reflected in the amount of red chili productivity per hectare reaching around 20 tons/ha (Syukur et al. 2015). Nonetheless, the magnitude of this productivity is often not achieved due to cultivation methods that have not been optimal, changes in weather, and pest and disease attacks. If the average production rate of red chili production is IDR15 tons/ha and the farmer's selling price is IDR $30,000 / \mathrm{kg}$, the amount of IDR450 million/ha/season will be obtained making this commodity one of the most prospective commodities to improve the welfare of farmers (Setiawati et al. 2017). To date, there are still farmers who have not been able to enjoy these benefits because of the large production costs and transaction costs faced by farmers who grow red chili. In running farming activities, in addition to calculating production costs, there are other types of costs that should also be calculated by farmers. When farmers conduct a transaction, there will be a transfer of goods/services from one party to another, both in terms of providing input and in selling output. This transaction activity raises transaction costs. For small farms, the total costs incurred by farmers are assumed to be not wholly calculated as they encounter difficulties in identifying the costs. Farmers frequently perceive the costs to be normal, and the need to take the costs into an account is unnecessary. The costs which are not calculated are assumed to be transaction costs. Even though the transaction costs are difficult to identify, the presence of these transaction costs will increase farming costs indirectly and also determine the net income received by farmers.

Various studies have tried to show how transaction costs can influence a farm's income. The results of research conducted by Sultan and Rachmina (2014) showed that the transaction costs will make the funding allocation increase. However, this can contribute to business improvement as the transaction costs are identified, the business profits can also be controlled properly.

Research on transaction costs in the scale of farming was carried out by Hadidjah (2012) stating that transaction costs affect farm households in making decisions of production, labor allocation, and consumption. On the other hand, Sultan and Rachmina (2014) also examined transaction costs related to the benefits of soybean farming. The results showed that transaction costs have a negative and significant effect on the benefits of soybean farming.

Transaction costs were conceptually introduced by Coase (1937) explaining that transaction costs are the costs of using the price mechanism. Furthermore, Coase (1960) also emphasizes that transaction costs are the costs of conducting transactions in open markets in which the costs are very diverse and ubiquitous. At the micro-level, transaction costs can be seen as something 
lost from the economy, in other words, all costs incurred by consumers that are not transferred to the seller, or the difference between the amount paid by the buyer and the amount received by the seller (Wang, 2003). These transaction costs must be borne by all parties who wish to conduct the transaction process.

All resources used in transactions will be aggregated into transaction cost economics (TCE). These transaction costs are still difficult to define depending on the case. In this research, the transaction costs in question are costs incurred in making a transaction, yet not directly related to the production process. The costs are not only in the form of nominal, but can also be not nominal in value. Transaction costs can be measured based on market value (Wang, 2003) and non-market value (De Soto, 1989). Non-market transaction costs can be in the form of resources spent in waiting conditions, activities to obtain business permits, distance, road conditions, etc.

The transaction costs can increase the total costs incurred in farming activity. The high and low transaction costs, incurred by farm households producing red chili as a result of transaction costs, will result in differences in prices received by consumers and prices received by producers. As mentioned earlier, transaction costs of raising the effective prices paid by buyers and lowering prices are effectively accepted by good sellers, creating a price band where some parties do not earn profits either by selling or by buying it (Key et al. 2000). In other words, the total costs incurred during the farming process do not include transaction costs. While it is known that total costs will affect the net income of farming, the level of income that could have been higher could not be realized because of the presence of transaction costs.

Based on this problem, the objectives of this research were (1) to analyze the structure of transaction costs on red chili farming; and (2) to analyze the variables which could affect the benefits of red chili farming.

This research conducted a survey and direct observation to obtain primary data, with existing scope and limitations. This research was only carried out at the level of farm household (producers) who planted red chili commodity in Garut Regency, West Java. The types of transaction costs analyzed in this research were only costs incurred in the process of farming (input) to harvest (selling decisions). This research has not analyzed further the tracing of transaction costs in marketing red chili starting from traders to consumers.

\section{METHODS}

The research was conducted in Garut Regency, West Java. The research location was chosen purposively with the consideration that the area is one of the largest centers of red chili production in Indonesia. In addition, Garut Regency also had the highest share in producing red chili by contributing $34.74 \%$ of total production in West Java or $6.45 \%$ of total national production (DPTH, 2015). This research was conducted from July to September 2017.

The type of data used was cross section data of 2017. The primary data were obtained by conducting in-depth interviews with the farm households who planted red chili. This research was also supported by secondary data obtained from the Central Statistics Agency, Ministry of Agriculture, journals, and other publication documents.

The data collection technique (research samples) was carried out by multistage purposive sampling. First, the selection of research areas was conducted i.e. West Java Province and Garut Regency as the research location. Second, the selected sub-district was determined based on the largest red chili production in Garut. Third, villages were selected based on the production of red chili. Fourth, respondents were selected randomly in which two sub-districts were selected, Cisurupan and Cikajang, with 145 respondents of farmers.

The data analysis technique in this study was carried out in accordance with the research objectives. Williamson (2000) stated that the transaction cost analysis unit is the transaction itself. Transaction costs cannot be calculated directly but are estimated using various approaches (proxy) (Gabre-Madhin, 2005) in which each component of transaction costs faced by farm households is not always the same. In managing red chili farming, transaction costs faced by farmers can be analyzed by calculating the total transaction costs $(\tau \mathrm{rC})$, using the following equation:

$$
\tau r C j=\sum Z_{i j}
$$


The ratio of each component of transaction costs to total transaction costs ( $\mathrm{z}$ ) was calculated using the following formula:

$$
z i j=\frac{Z i j}{\tau r C j} ; \quad \sum z i j=1
$$

The economic efficiency level of farm household can be seen from the ratio of transaction costs to farmer's income. The ratio of transaction costs to farm household income can be calculated using the formula:

$$
\frac{z_{j}}{y_{j}}=\frac{\operatorname{\tau r} C_{j}}{B_{j}}
$$

To determine the proportion of transaction costs on the overall costs incurred by farm households in production activities, the proportion of transaction costs on total costs was calculated (the sum of production costs and transaction costs) using the following formula:

$$
r t c_{j}=\frac{\tau r C_{j}}{\left(\tau C_{j}+\tau r C_{j}\right)}
$$

in which: $\tau \mathrm{rCj}$ = Total transaction cost (IDR/year), zij = Transaction cost components (IDR/year), $\mathrm{B}_{\mathrm{j}}=$ Revenue (IDR/year), $\mathrm{rtc}_{\mathrm{j}}=$ Ratio of transaction cost to total cost, $\tau \mathrm{C}_{\mathrm{j}}=$ Total production cost (IDR/year)

The data were analysed to examine the factors that affected the profits of red chili farming by profit function analysis normalized by the unit output price of the Cobb-Douglas profit function (UOP-CDPF). The benefits of red chili farming (PROFC) were presumably affected by normalized chili seed prices (IHBC), manure costs (IHPPK), insecticide prices (IHOBT), normalized labor wages (IUTK), NPK fertilizer prices (IHNPK), and transaction costs (BTC). This analysis was useful to examine the factors that affected the benefits of red chili farming as follows:

$$
\begin{aligned}
\mathrm{LnPROFC}= & \beta_{0}+\beta_{1} \mathrm{IHBC}+\beta_{2} \mathrm{IHPPK}+\beta_{3} \mathrm{IHOBT}+ \\
& \beta_{4} \mathrm{IUTK}+\beta_{5} \mathrm{IHNPK}+\beta_{6} \mathrm{BTC}+\mu_{\mathrm{i}}
\end{aligned}
$$

in which: $\beta_{0}=$ intercept $/$ Constanta, $\beta_{1} \ldots . \beta_{6}=$ Regression coefficient for each independent variable, $\mu_{\mathrm{i}}=$ error term.

Based on the theoretical and operational exemplifications, the hypotheses of this research were: (1) transaction costs on red chili farming which covered the costs of information search, implementation, sales intermediary, trading partner finding, and negotiation;
(2) chili prices, manure costs, NPK fertilizer prices, labor costs, chili cultivation areas, education, and transaction costs were considered to have significant effects on the red chili farming benefits.

Transaction costs play an important role in farming activities. In various research results, transaction costs have been assumed in various different forms and meanings according to the research objectives. In general, different transaction costs are caused by differences in the resource allocation, limitations in processing information received (imperfect information), and also uncertainties. Farmers in small and medium scale often faces difficulty or incapability to distinguish costs incurred in their farming.

Farmers usually only calculate production costs without taking into account other costs beyond production costs, while there are transaction costs that must also be noticed apart from the production costs. The transaction costs can increase the total costs incurred in farming. According to Matungul et al. (2006), the high costs incurred in farming activities will result in differences in prices received by producers (input market) from prices received by consumers (output market). Therefore, the calculation of transaction costs is important for farmers, so that they can reduce existing costs andincrease the revenue that should be received. The amount of transaction costs will affect farmers' income which can be seen through the ratio of transaction costs to revenues. The number of this ratio determines the economic efficiency level of red chili farming in terms of transaction costs. Research framework in Figure 1.

\section{RESULTS}

\section{The Structure of Transaction Cost on Red Chili Farming}

In conducting transactions, farmers do not only take into account the costs spent on producing items or services but also have to consider the amount of money to spend to conduct the transaction. Transaction costs include not only the transaction costs but also the costs of reorganizing household labours and other resources to be able to access the market (Makhmura et al. 2001). The types of transaction costs in this research consisted 
of fixed transaction costs and transaction cost variable arising as a result of exchanging property rights (Key et al. 2000 and Makhura et al. 2001).

Each farm household would face different transaction cost structures caused by differences in the farming scale managed by farm households as shown in Table 1. Based on the results of previous studies, there are several classifications of transaction costs. Transaction costs in this research consisted of: (1) information search costs; (2) implementations costs, (3) trading partner searching costs; (4) sales intermediary costs; (5) negotiation costs. These were presented in the types of transaction costs and transaction cost components in red chili farming in Garut Regency, West Java.

The search cost covers costs incurred to obtain information on business interests or profits or losses of an exchange/transaction (North and Thomas, 1973; Baye, 2010). Implementation cost includes a transaction or costs incurred for each activity conducted (North \& Thomas, 1973; Moss, 2013). The cost of finding a trading partner incurred to look for trading partners and to reduce existing risks so that farmers can avoid losses. Sales intermediary costs incurred for marketing agricultural products. Negotiation costs incurred when negotiating with others who are potential to work together (Williamson, 1989; Hobbs, 1997; Baye, 2010).
Table 2 highlighted that the transaction cost component in financing red chili farming with the highest percentage is the implementation cost. This cost consists of red chili seedling production (complong), arranging capital loans, labor costs, transportation costs for purchasing output, and fertilizer delivery costs.

The information search cost is the second highest transaction cost component issued by red chili farm households. This search cost is issued to find, obtain, and use knowledge (information) about resources. Discussions of strategies farmers must do in the use of inputs, production process, and output marketing push the farmers to pay to obtain this information. These costs include the cost of purchasing balance to search for information sources using the help of communication devices (mobile phones), and hearing costs which incurred to access all information without using tools.

Another component of transaction costs that is also included in transaction costs of red chili farming is the cost of negotiation. Negotiation cost is in the third highest percentage of $22.3 \%$ after implementation and information search costs. The amount of transaction costs at the negotiation costs is dominated by the costs incurred to maintain the land contract (land tax). This is also in line with the research of Sultan and Rachmina (2014) arguing that the large cost to maintain land contracts is the main factor determining the value of the transaction cost components.

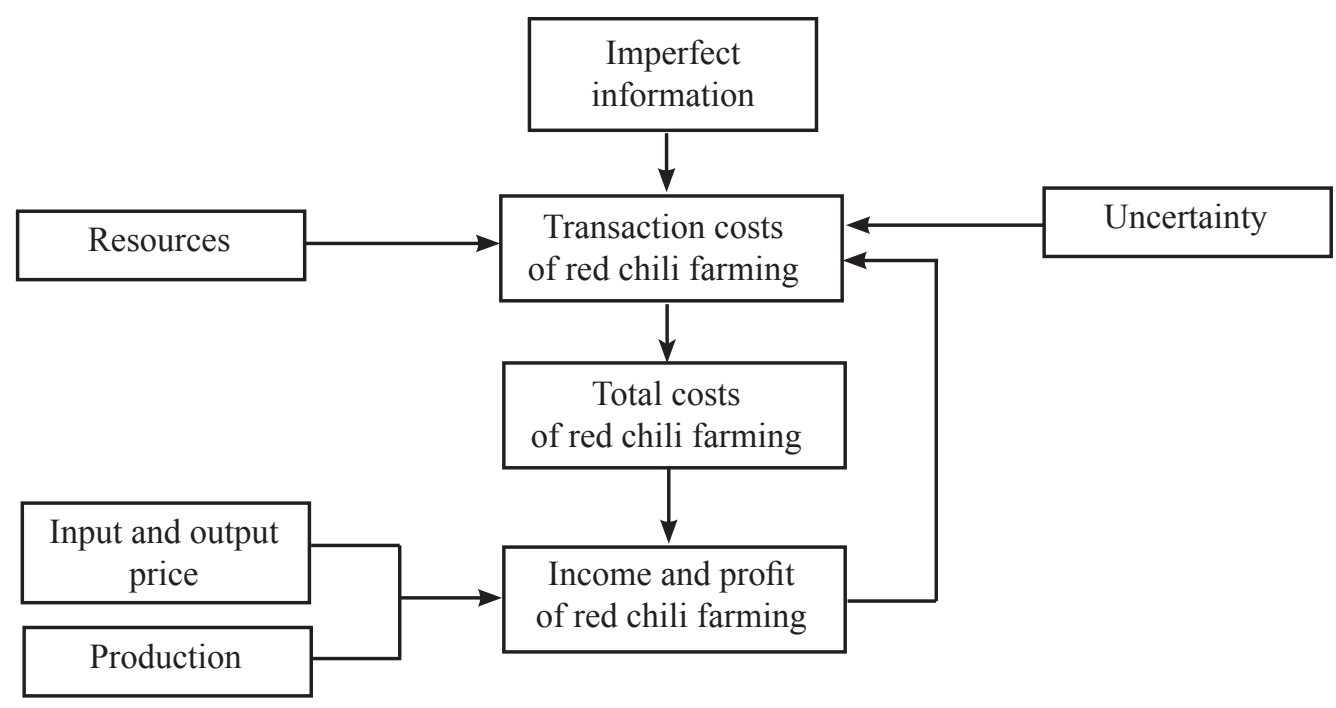

Figure 1. Research framework 
Table 1. Transaction cost structure on red chili farming

\begin{tabular}{ll}
\hline Transaction Cost Types & Transaction Cost Components \\
\hline Information Search Cost & Phone balance cost \\
& Hearing Cost \\
Implementation Cost & Seedling production cost \\
& Loan processing cost \\
& Labour activity cost \\
& Input purchasing transport cost \\
& Fertilizer delivery cost \\
& Trading partner search cost \\
Trading partner search cost & Harvest delivery cost \\
& Commission of sales intermediary cost \\
Sales intermediary cost & The cost of chili damage risk avoidance \\
& Cost to maintain contract (tax/land rent) \\
Negotiation cost & Negotiation cost \\
\hline
\end{tabular}

Table 2. Transaction cost components on funding red chili farming

\begin{tabular}{lcc}
\hline Transaction Cost Component & Amount (IDR/year) & Percentage (\%) \\
\hline Information search cost & $921,365.52$ & 23.1 \\
Implementation cost & $1,002,161.38$ & 25.1 \\
Trading partner search cost & $311,976.21$ & 7.8 \\
Sales Intermediary Cost & $863,672.90$ & 21.6 \\
Negotiation cost & $891,551.74$ & 22.3 \\
Total of transaction costs & $3,990,727.74$ & 100 \\
\hline
\end{tabular}

Sales intermediary costs and and partner search costs have percentages of $21.6 \%$ and $7.8 \%$. Both transaction costs are incurred in order to make decisions regarding the sales of agricultural products. Considering that red chili is a commodity that must be sold in fresh form and its condition is perishable, making the sales intermediary often imposes sales risks to farmers. Behavior or actions taken by farmers to avoid the sales risk are parts of transaction costs.

\section{Ratio of Transaction Cost to the Revenue and Production Cost of Red Chili Farming}

Red chili commodity in Garut Regency faces fluctuating price risks. High price fluctuations cause fluctuations in revenue and profit of red chili farming obtained by farmers from the results of their farming activities. This non-conducive condition certainly results in an unstable profit obtained by farmers. High profit level is the main attraction for farmers to plant red chili. Interest in growing red chili can be assessed from the amount of farms' income received. High income can be obtained by seeking the maximum revenue from farming with the lowest production costs.
Revenue of red chili farming can be seen in Table 3. Revenue is the multiplication of production obtained by the selling product price. Gross revenue or income is the overall production value before being deducted by production costs. Net income (profit) of farming is the difference between revenue and total costs. The profit of red chili farming is obtained after being reduced by the total farming costs of IDR75,721,231.09. After the total cost and profit of farming is identified, the ratio of transaction costs to farming costs and also to farming profit will be obtained.

As explained above, the transaction costs in this research consisted of information searchcosts, implementation costs, trading partner search costs, intermediary sales costs, and negotiation costs. This transaction costs arises due to the transfer of property rights. Transaction costs represent costs for land, labor, capital, and entrepreneurial skills needed to transfer property rights from one party to another. However, if transaction costs are at a minimal level, property rights are unimportant to the general concept of efficiency because property rights can be adjusted and changed voluntarily to encourage an increase in the production process. 
Transaction costs analyzed in this research were aggregated transaction costs from the economy in which the total cost incurred by farmers in production activities was the accumulation of production costs and transaction costs. Table 4 shows that the average total cost incurred by farmers was IDR14,020,252.27 per year. When the ratio of transaction costs to total costs incurred in production activities is calculated, the value ratio of 0.0285 will be obtained. This value indicates that the proportion of transaction costs incurred by farmers in red chili farming production activities is $2.85 \%$ of the total cost. The greater the ratio value of the transaction costs to total costs, the more inefficient the production process of red chili farming (Saidah, 2018).

Based on this explanation, the presence of a transaction cost component in red chili farming will result in an increase in total costs (Saidah, 2018). The smaller the transaction costs that can be reduced, the smaller the total cost will be. This certainly will also affect the selling price of fresh red chili at the farm level so that there is a connection between transaction costs and red chili prices and efforts to improve farmers' welfare.

In addition to the ratio of transaction costs to total costs, the ratio of transaction costs to farm revenue and profit can also be calculated as shown in Table 5 below. In farming activities, farmers will usually take into account and compare revenue and cost in which the higher the ratio, the more profitable the farming. Basically, farmers are not only interested in increasing their production but also in increasing their income from farming. The amount of farmers' income from red chili farming is affected by the large production and selling price of red chili. The greater the production produced, the higher the selling price received by farmers; then, the income obtained is also higher, and vice versa.

Transaction costs can also be a factor that affects farming profits as Martin et al. (2010) argued that transaction costs give rise to uncertainty. The amounts of transaction costs for the revenue and profit of red chili farming are 4.65 and 5.27, respectively. These values indicate that the proportions of transaction costs to the revenue and profit of red chili farming is respectively $4.65 \%$ and $5.27 \%$ of the total cost. The greater the ratio of transaction costs to farm revenue and profit, the more reduced the revenue and profit obtained from red chili farming. The amount of transaction costs generated from the ratio highlighted ignorance and inability of farmers to identify transaction costs included in red chili farming.

\section{The Effect of Transaction Cost on the Profit of Red Chili Farming}

Based on the results of variance analysis by using OLS (Ordinary Least Square) method, the profit model on red chili farming is shown in Table 6. The numbers of observations in multiple regression analysis were 145 samples. The value of $F(11,131)$ by 11.65 indicated that the number of variables tested was 11 pieces, and the number of observations minus the number of variables equalled to 131 with an $\mathrm{F}$ value of 11.65 . The probability value $>$ F of 0.0000 smaller than $\alpha(\alpha=5 \%)$ showed that independent variables in the regression model were $62.86 \%$, while the remaining $37.14 \%$ were influenced by other variables. Thus, it can be said that the overall model is good and can exemplify the red chili farming profit variables.

In general, there are 7 variables that have significant effects at the $5 \%$ level on the profits of red chili farming in Garut Regency; i.e. the prices of chili (HC), manure (IHPPK), NPK fertilizer (IHNPK), labor wage (IUTK), chili cultivation area (LC), education (EDU), and transaction costs. There is one variable that has a significant effect at the $10 \%$ level i.e. farming experience (EXP).

Table 3. Revenue average of red chili farming in garut regency

\begin{tabular}{lcc}
\hline Variable & Amount (IDR) & Total \\
\hline Red chili production (kg/year) & $7,131.55$ & \\
Red chili price (Rp/kg/year) & $12,024.14$ & \\
Red Chili revenue (IDR/year) & & $85,750,755.62$ \\
Production Cost (IDR/year) & & $10,029,524.53$ \\
Farming Profit (IDR/year) & & $75,721,231.09$ \\
\hline
\end{tabular}


Table 4. Transaction cost and total cost of red chili farming

\begin{tabular}{lc}
\hline Component & Total \\
\hline Transaction Cost (IDR) & $3,990,727.74$ \\
Production Cost (IDR) & $10,029,524.53$ \\
Total Cost = Transaction Cost + Production Cost (IDR) & $14,020,252.27$ \\
Transaction Cost Percentage - Total Cost & 2,85 \\
\hline
\end{tabular}

Table 5. Percentages of transaction cost, revenue, and profit of red chili farming

\begin{tabular}{lcc}
\hline Components & Total & Percentage $(\%)$ \\
\hline Transaction Cost (IDR/year) & $3,990,727.74$ & \\
Revenue (IDR/year) & $85,750,755.62$ & \\
Profit (IDR/year) & $75,721,231.09$ & 4,65 \\
Transaction Cost Percentage/Revenue & & 5,27 \\
Transaction Cost Percentage/Profit & & \\
\hline
\end{tabular}

Table 6. Results of parameter estimation of the profit equation of red chili farming

\begin{tabular}{|c|c|c|c|c|c|}
\hline Variable & & Coefficient & Standard Errors & t-value & $\mathrm{P}>|\mathrm{t}|$ \\
\hline Chili price (IDR) & & $0.7072 *$ & 0.1243 & 5.69 & 0.000 \\
\hline Manure price (IDR/kg) & & $-1.1433^{*}$ & 0.1414 & -8.09 & 0.000 \\
\hline Insecticide price (IDR/lt) & & $-0.1979 *$ & 0.8629 & -2.29 & 0.023 \\
\hline Labour wages (IDR/HOK) & & $0.7798 *$ & 0.1022 & 7.63 & 0.000 \\
\hline NPK fertilizer cost (IDR/kg) & & 0.0039 & 0.0067 & 0.59 & 0.554 \\
\hline Transaction cost (IDR/year) & & $-0.6810^{*}$ & 0.0549 & -12.39 & 0.000 \\
\hline \multirow[t]{3}{*}{ Constanta } & & 5.2541 & 0.7963 & 6.60 & 0.000 \\
\hline & Number of Obs & 145 & & Prob $>$ F & 0.0000 \\
\hline & $\mathrm{F}(6,138)$ & 165.53 & & R-sguared & 0.8727 \\
\hline
\end{tabular}

Note: $*=$ Significant at 5 percent level

The variable price of chili (HC) has a positive and significant sign for the profits of red chili farming. This means that the higher the price of red chili earned by farmers, the higher the profits earned. The red chili selling price is an agricultural product that has no government intervention in its marketing flow so that the price depends on the market mechanism. The selling price of red chili at the level of farmers in Garut is very fluctuated. In certain conditions, the price of red chili can reach IDR90,000, and in other conditions, it can decrease by IDR3,000. These price fluctuations are caused by the unsustainable supply of red chili from production centers to markets.

The price of manure normalized with chili prices (IHPPK) has a negative sign indicating that if there is an increase in the price of manure, it will reduce the profitability of red chili farming. One way to increase the yield of red chili cultivation can be carried out through fertilizer application. Manure for red chili plants is useful for providing fertility and supplying nutrients to the soil so that the plants become fertile.

If farmers aim at maximum results, use of manure must be conducted at least 3 times; i.e. as a basic fertilizer before planting red chili after the plants are one month old, and when the plants start to flower and bear fruit. The decrease in the frequency of fertilization caused by the inability of farmers to buy fertilizers has resulted in a decrease in the production of red chili and will also indirectly reduce the profits received by farmers.

The variable of NPK fertilizer price (IHNPK) has a negative and significant sign for the profits of red chili farming, indicating that the increase in NPK fertilizer prices will reduce the profits of red chili farming. Fertilization in red-leaf plants can be conducted in 3 ways; i.e. casting, tugal, and foliar (leaf fertilizer), or 
a combination of the three. Fertilizer needs for red chili plants are conditional meaning that each phase of chili growth has different fertilizer needs. The fertilizer needs will increase along with the increasing growth phase.

The parameters of laborwages that have been normalized with chili prices (IUTK) have a positive and significant sign for the profits of red chili farming. This condition occurs because of the behavior of farm households with a tendency to recruit more workers, especially at harvest time. As the frequency of harvesting of red chili increases, the labor costs also increase, but the production yields obtained from the high frequency of chilli harvest can cover labor costs.

The variable of chili land cultivation area (LC) has a positive and significant sign for the profits of red chili farming. Variables of chili cultivation area positively marked can indicate that the wider areas cultivated by farmers, the higher the farmers' profits of red chili farming. This is in line with the results of Sultan's research (2015) stating that the greater the area of land owned by farmers, the higher the profits earned by farmers.

The education variable (EDU) has a positive and significant sign at the $5 \%$ level on the profits of red chili farming. Education can indirectly affect the mindset of farmers in which the higher the education level they have, the higher the motivation seen in farmers' behavior to achieve certain level of income (Kapale, 2012). The same goes for farming experience (EXP) in reference to the results of the research that the respondents had more than 10 years of experience on average. This should be an opportunity for farmers to further develop their creativity in running their farming activities in order to earn more income.

Transaction cost variable (BTC) has a negative and significant sign for the profits of red chili farming. This means that the higher transaction costs faced by farmers, the more reduced the profits of red chili farming.

\section{Managerial Implications}

Based on the results of the research, it can be inferred that farmers have the ability to process and use available information, as a result, they face incomplete information and uncertainty. The behavior of farmers who are unable to process information is a distinct advantage for opportunistic actors (traders) in their efforts to obtain dishonest profits in transaction activities. This trade-off practice will certainly cause transaction costs as a result of imperfect information, in which the amount of the transaction costs varies for each farmer. Therefore, to reduce existing transaction costs, the role of extension agents is needed through close relations within the community. In addition, the government must also pay more attention to the role of institutions such as cooperatives and farmer groups in reducing transaction costs that can also be done through improving facilities and services to farmers both in providing inputs and in marketing the harvests.

\section{CONCLUSIONS AND RECOMMENDATIONS}

\section{Conclusions}

The structure of transaction costs on red chili farming consists of information search costs, implementation costs, trading partner search costs, and negotiation costs. The highest component of transaction costs is the cost of finding a trading partner by $25.1 \%$ and the lowest transaction cost was the cost of finding a trading partner by $7.8 \%$. Variables that significantly affected farms' profits were the prices of chili seeds, manure prices, prices of insecticides, labor wages, and transaction costs. Transaction cost is one factor that can reduce the profits of red chili farming.

\section{Recommendations}

Transaction costs play a significant role in the decisions of farmers' household resource allocation where transaction costs in agriculture are related to three main things, namely contracts and property rights issues, organizations and institutional arrangements and market exchanges. The process of how resources are allocated and the role of transaction costs in an agricultural transaction, especially in farm household decisions, are engaged in market exchanges both in the input and output markets. One approach that can be used to explain transaction costs is to see through economic aspects in terms of institutions. The amounts of transaction costs on red chili farming can be reduced by redesigning the rules of the game on non-market institutions to protect the market from endless failure. 


\section{ACKNOWLEDGMENT}

Gratitude is expressed to the Ministry of Technology and Higher Education Research for providing scholarships while the author attended a doctoral program at the Bogor Agricultural University Graduate School, Doctoral Dissertation Grants in 2018, as well as Research Output Quality Improvement Workshop, Research Scholarship Dissertation Program, and Research Capacity Improvement Program 2018. The author also expressed gratitude to the Department of Social Economics and Agriculture, Faculty of Agriculture, Padjadjaran University, for giving the opportunity and trust to take a doctoral program at the Graduate School of the Bogor Agricultural University. In addition, gratitude was also served for the village officials who had given trust to carry out this research program so that this research could be completed properly.

\section{REFERENCES}

Coase R. 1937. The nature of firm. Economica, New series 4(16): 386-405. https://doi.org/10.1111/ j.1468-0335.1937.tb00002.x.

Coase R. 1960. The problem of social cost. Journal of Law and Economics 3: 1-44. https://doi. org/10.1086/466560.

[DTPH] Dinas Tanaman Pangan dan Hortikultura Kabupaten Garut. 2015. Laporan Tahunan Dinas Tanaman Pangan dan Hortikultura Kabupaten Garut. Garut: Dinas Tanaman Pangan dan Hortikultura Kabupaten Garut.

Baye MR. 2010. Managerial Economics and Business strategy. New York:Mc Graw-Hill.

De Soto H. 1989. The Other Path: the Invisible Revolution in the Third World. New York: Harper \& Row.

Gabre-Madhin, Eleni Z. 2005. The Role of Intermediaries in Enhancing Market Efficiency in the Eithiopian Grain Market. Agriculural Economics 25(2-3): 311-32. https://doi. org/10.1016/S0169-5150(01)00088-3.

Hadidjah F. 2012. Analisis perilaku ekonomi rumahtangga petani usaha ternak sapi kelapa dalam menghadapi biaya transaksi di Kabupaten Bolaang Mongondow. Jurnal Pengkajian dan Pengembangan teknologi Pertanian 12(3).

Hobbs JE. 1997. Measuring the importance of transaction costs in cattle marketing. American
Journal of Agricultural Economics 79(4): 1082 1095. https://doi.org/10.2307/1244266.

Kapale R. 2012. Factor-faktor yang mempengaruhi tingkat kemiskinan di Kota Ambon. Jurnal Agrilan 1(1): 101-115.

Key N, Sadoulet E, de Janvry A. 2000. Transactions costs and agricultural household supply response. American Journal of Agricultural Economics 82(2): 245-59. https://doi.org/10.1111/00029092.00022

Makhmura M. 2001. Overcoming transaction costs barriers to market participation of smallholder farmers in the Northern of South Africa [dissertation]. Pretoria: University of Pretoria.

Makhura M, Kirsten J, Delgado C. 2001. Transaction costs and small holder participation in the maize market in the Northern Province of South Africa. Paper presented at the Seventh Eastern and Southtern Africa Regional Conference, Nairobi, Kenya, Februari 5-11.

Martins R et al. 2010. Transaction cost theory influence in strategy research: a review through a bibliometric study in leading journals. Working paper No.61/2010 April. Advantage Center of Research in International Business and Strategy. Matungul PM, Ortmann GF, Lyne MC. 2006. Marketing methods and income generation amongst small-scale farmers in two communal areas of kwazulu-Natal, South Africa. Journal School of Agricultural Sciences and Agribusiness. $8(32): 445-462$.

Moss CB. 2013. Agricultural Finance. New York: Routledge. https://doi. org/10.4324/9780203549353.

North, Thomas.1973. Transaction cost - dictionary definition of transaction cost. http://economics. about.conv/library/glossary/blglossary-full.htm. [8 July 2018].

Nurhayanti Y. 2017. Fluktuasi dan disparitas harga cabai Indonesia. Academia.edu. [2 Desember 2018].

[Pusdatin] Pusat Data dan Sistem Informasi Pertanian. 2017. Statistik Konsumsi Pangan Tahun 2017. Jakarta: Kementrian Pertanian.

Saidah Z. 2018. Analisis biaya transaksi dan biaya produksi pada usahatani cabai merah (Capsicum annum L). Journal of Scientech Research 2(1): $27-40$.

Saptana et al. 2010. Strategi manajemen resiko petani cabai merah pada lahan sawah dataran rendah di Jawa Tengah. Jurnal Manajemen dan Agribisnis 
7(2): 115-131.

Saptana, NK Agustin, Ar-Rozi AM. 2012. Kinerja Produksi dan Harga Komoditas Cabai Merah. Laporan Akhir Anjak 2012. Bogor: PSEKP.

Setiwati W, Koesandriani Y, Hasyim A. 2017. Sumbangsih cabai keriting varietas kencana dalam menghadapi kebijakan swasemada cabai. https:/hortikultura.litbang.pertanian.go.id. [16 Juli 2018].

Sultan H, Rachmina D. 2014. Pengaruh biaya transaksi terhadap keuntungan usahatani kedelai di Kabupaten Lamongan Jawa Timur. https:// media.neliti.com/media/publications/61651-IDpengaruh-biaya-transaksi-terhadap-keuntu.pdf. [16 July 2018].

Suwarsinah HK et al. 2018. The pricing system of red onion and red chili commodities. Jurnal
Manajemen dan Agribisnis 15(2):150-161. https://doi.org/10.17358/jma.15.2.150.

Syukur M, Sujiprihati, Yunianti. 2015. Teknik Pemuliaan Tanaman. Edisi Revisi. Jakarta: Penebar Swadaya.

Wang N. 2003. Measuring Transaction Cost: An Incomplate Survey. Ronal Coase Institute Working Paper.

Williamson OE. 2000. The new institutional economics: taking stock, looking ahead. Journal of Economic Literatur 38(3):595-613. https://doi. org/10.1257/jel.38.3.595.

Yanuarti AR, Afsari MD. 2016. Profil komoditas barang kebutuhan pokok dan barang penting komoditas cabai. https://ews.kemendag.go.id/ download. aspx?file=BK_CABAI_16-03-2018-SP2KP [16 November 2018]. 